\title{
KEEFEKTIFAN PENDEKATAN CTL TERHADAP HASIL BELAJAR IPA MATERI SUMBER DAYA ALAM
}

\author{
Desi Wulandari, Nuning Setyowati \\ wulanipa@mail.unnes.ac.id
}

Jurusan Pendidikan Guru Sekolah Dasar, Fakultas Ilmu Pendidikan, Universitas Negeri Semarang.

\begin{abstract}
Abstrak
Penelitian in bertujuan untuk mengkaji keefektifan pendekatan Contextual Teaching and Learning terhadap hasil belajar IPA materi sumber daya alam kelas IV SDN Wonosari 01. Jenis penelitian yang digunakan adalah eksperimen kuasi (quasi experimental) dengan desain Nonequivalent Control Group Design. Subjek penelitian adalah seluruh siswa kelas IV SDN Wonosari 01. Sampel yang digunakan adalah siswa kelas IVA (kelas eksperimen) dan siswa kelas IVB (kelas kontrol). Teknik pengambilan sampel menggunakan teknik sampling jenuh. Penelitian ini adalah penelitian populasi. Data hasil belajar siswa menunjukkan bahwa rata-rata nilai posttest kelas eksperimen lebih besar dibandingkan kelas kontrol. Mean posttest kelas eksperimen sebesar 73,45 dan mean posttest kelas kontrol sebesar 57. Hasil uji-t menunjukkan nilai $t_{\text {hitung }}(4,707)>t_{\text {tabel }}$ $(1,728)$ berarti bahwa hasil belajar siswa dengan menggunakan pendekatan CTL lebih besar dibandingkan pendekatan konvensional. Nilai N-Gain kelas kontrol sebesar 0,26 (rendah) dan kelas eksperimen 0,50 (sedang). Hasil tersebut memberikan kesimpulan bahwa pendekatan CTL lebih efektif dibandingkan pendekatan konvensional.
\end{abstract}

Kata kunci :

Contextual teaching and learning approach; effectiveness; natural resource; learning outcomes; science 


\section{PENDAHULUAN}

Salah satu permasalahan pendidikan yang dihadapi sekolah pada umumnya adalah kurang optimalnya mutu pendidikan. Hal ini dapat dilihat dari lemahnya proses pembelajaran seperti pada metode, pendekatan atau model pembelajaran yang digunakan guru masih menggunakan model konvensional. Upaya untuk mengoptimalkan mutu pendidikan salah satunya adalah memperbaiki kurikulum yang lebih memberdayakan peserta didik.selain itu, mutu pendidikan juga sangat ditentukan oleh pendekatan-pendekatan yang digunakan para guru dalam proses pembelajaran untuk mencapai tujuan pendidikan. Ketepatan dalam menggunakan pendekatan pembelajaran yang dilakukan oleh guru akan dapat membangkitkan motivasi dan minat siswa terhadap materi pembelajaran serta terhadap proses dan hasil belajar siswa. Siswa akan mudah menerima materi yang diberikan oleh guru apabila pendekatan pembelajaran yang digunakan tepat dan sesuai dengan tujuan pembelajarannya.

Adapun permasalahan yang dihadapi di SDN Wonosari 01 Kota Semarang pada pembelajaran IPA kelas IV adalah sebagai berikut: (1) pembelajaran belum dikaitkan dengan situasi dunia nyata dan kehidupan sehari-hari, sehingga siswa belum dapat membangun pemahamannya terhadap materi pembelajaran, (2) kegiatan apersepsi kurang menantang, karena siswa belum diajak untuk membangun pemahaman mereka tentang pengalaman baru berdasarkan pengetahuan awal, (3) siswa kurang diberikan motivasi untuk berpikir kritis dan menemukan pengetahuan secara mandiri, (4) guru belum mendorong siswa untuk menggali informasi melalui pertanyaan-pertanyaan, (5) belum adanya pembentukan kelompok untuk membentuk kerjasama siswa, (6) pemanfaatan media pembelajaran kurang optimal, serta kurangnya pemodelan yang berkaitan dengan materi ajar, dan (7) penilaian baru meliputi aspek kognitif, guru belum melakukan penilaian terhadap keterampilan siswa.

Hal ini relevan dengan hasil Ulangan Akhir Semester (UAS) I mata pelajaran IPA siswa kelas IV SDN Wonosari 01 diperoleh data sebagai berikut: di kelas IV A terdapat 6 siswa $(27,27 \%)$ dari 22 siswa yang tidak mencapai Kriteria Ketuntasan Minimal (KKM) yaitu sebesar 65. Sedangkan di kelas IV B, dari 26 siswa terdapat 11 siswa (42,31\%) yang tidak mencapai KKM dan hanya 15 siswa (57,69\%) yang mendapat nilai di atas KKM. Berdasarkan hasil belajar dan permasalahan yang ditemu-kan, maka pembelajaran IPA kelas IV SDNWonosari 01 merupakan permasalahan yang sangat penting dan mendesak untuk dicari pemecahannya agar kualitas pembelajaran IPA meningkat dan tujuannya tercapai secara maksimal.

Berpijak pada teori belajar kontruktivisme dan permasalahan yang ada pe-neliti merencanakan penelitian eksperimen de-ngan menerapkan pendeketan pembelajaran inovatif yang diharapkan dapat meningkatkan kualitas pembelajaran meliputi aktivitas dan hasil belajar siswa. Pembelajaran inovatif me-ngutamakan peran guru sebagai fasilitator, motivator, evaluator, dan juga informator. Salah satu pendekatan pembelajaran inovatif yaitu pendekatanContextual Teaching and Learning (CTL).

Contextual Teaching and Learning (CTL) merupakan suatu proses pendidikan yang holistik dan bertujuan memotivasi siswa untuk memahami makna materi pelajaran yang dipelajarinya, dengan mengaitkan materi tersebut dengan konteks kehidupan sehari-hari (konteks pribadi, sosial, dan kultural), sehingga siswa memiliki pengetahuan/keterampilan yang secara fleksibel dapat diterpkan (ditransfer) dari satu permasalahan/konteks ke permasalahan/konteks lainnya (Putra, 2013). 
Penelitian yang mendukung penelitian ini adalah penelitian yang dilakukan oleh Shawn M. Glynn dan Linda K. Winter (2004) yang berjudul "Contextual Teaching and Learning of Science in Elementary Schools". Selain itu, terdapat peneltian yang dilakukan oleh Hudson dan Wishler (2011) dengan judul "Contextual Teaching and Learning for Practicioners" menyatakan bahwa CTL memiliki kelebihan bahwa CTL mampu membantu siswa mem-bangun pengetahuan mereka sendiri dengan ca-ra membimbing mereka melalui skenario di-mana mereka diwajibkan untuk secara aktif mengeksplorasi konten untuk mencapai tujuan, memecahkan masalah, menyelesaikan sebuah proyek, atau menjawab pertanyaan.

Rumusan masalah dalam penelitian ini adalah: apakah pendekatan CTL (Contextual Teaching and Learning) lebih efektif diban-dingkan pendekatan konvensional terhadap hasil belajar IPA materi sumber daya alam siswa kelas IV SDN Wonosari 01?

Untuk memecahkan masalah, peneliti melaksanakan penelitian eksperimen guna mengkaji keefektifan pendekatan CTL. Adapun komponen pendekatan CTL menurut Rusman (2014: 193-199) yang telah dimodifikasi sesuai dengan materi sumber daya alam adalah sebagai berikut: (1) guru mempersiapkan media pembelajaran dan mengkondisikan siswa untuk siap mengikuti pembelajaran; (2) guru mela-kukan apersepsi dengan membuka pengetahuan awal siswa tentang sumber daya alam dengan mengaitkannya dengan kehidupan sehari-hari; (3) guru menggali pengetahuan siswa tentang macammacam sumber daya alam; (4) guru membagi siswa menjadi beberapa kelompok; (5) guru memberikan tugas kepada setiap kelompok untuk mengamati, menganalisis, dan menya-jikan hasil pengamatan secara tertulis tentang sumber daya alam; (6) guru meminta siswa un-tuk menyampaikan hasil diskusinya di depan kelas; (7) guru memberikan umpan balik atas hasil kerja kelompok siswa; (8) guru menam-pilkan contoh sumber daya alam yang belum ditemukan di sekitar lingkungan sekolah; (9) gu-ru mengajak siswa melakukan refleksi pembe-lajaran; dan (10) guru melakukan penilaian dari kegiatan berkelompok, dan memberikan tes tertulis.

Tujuan penelitian ini untuk mengkaji keefektifan pendekatan CTL terhadap hasil be-lajar IPA materi sumber daya alam siswa kelas IV SDN Wonosari 01.

\section{METODE PENELITIAN}

Penelitian ini merupakan penelitian eksperimen kuasi (quasi experimental) dengan desain Non Equivalent Control Group Design. Subjek penelitian terdiri dari 48 siswa. Penelitian ini adalah penelitian populasi yang terdiri dari 22 siswa kelas IV A (kelas ekspe-rimen) dan 26 siswa kelas IV B (kelas kontrol). Adapun desain penelitian tersebut dapat digam-barkan sebagai berikut (Sugiyono, 2015:116).

\begin{tabular}{llll}
\hline $\mathbf{R}$ & $\mathbf{O 1}$ & $\mathrm{X}$ & $\mathrm{O} 2$ \\
$\mathbf{R}$ & $\mathrm{O} 3$ & & $\mathrm{O} 4$
\end{tabular}

\section{Gambar 1. Desain Non Equivalent Control Group Design}

Keterangan:

$\mathrm{R} \quad$ : Kelompok eksperimen dan kelompok kontrol 
O1 : Hasil pretest kelompok eksperimen

O3 : Hasil pretest kelompok kontrol

$\mathrm{X}$ : Treatment/perlakuan

O2 : Hasil posttest kelompok eksperimen

O4 : Hasil posttest kelompok kontrol

Sumber data penelitian ini berasal dari siswa dan guru. Variabel terikat padapenelitian ini adalah hasil belajar IPA siswa pada materi sumber daya alam. Variabel bebasnya adalah pendekatan CTL. Teknik pengumpulan data hasil belajar menggunakan tes pilihan ganda dan uraian. Data hasil belajar dianalisis dengan uji-t dan uji N-Gain.

\section{HASIL PENELITIAN DAN PEMBAHASAN}

Data hasil belajar terdiri dari pretest dan posttest. Hasil belajar pretest di kelas kontrol dan kelas eksperimen berdistribusi normal serta homogen. Sedangkan rata-rata hasil posttest kelas eksperimen lebih dari kelas kontrol.

\section{Tabel 1.}

Hasil Belajar Pretest dan Posttest

\begin{tabular}{|c|c|c|c|c|c|c|c|c|c|}
\hline \multirow{3}{*}{ No. } & \multirow{3}{*}{ Interval } & \multicolumn{4}{|c|}{ Pretest } & \multicolumn{4}{|c|}{ Posttest } \\
\hline & & \multicolumn{2}{|c|}{ Kelas Kontrol } & \multicolumn{2}{|c|}{ Kelas Eksperimen } & \multicolumn{2}{|c|}{ Kelas Kontrol } & \multicolumn{2}{|c|}{ Kelas Eksperimen } \\
\hline & & $\mathrm{F}$ & $\%$ & $\mathrm{~F}$ & $\%$ & $\mathrm{~F}$ & $\%$ & $\mathrm{~F}$ & $\%$ \\
\hline 1 & $81-100$ & - & - & - & - & 3 & $12 \%$ & 5 & $23 \%$ \\
\hline 2 & $76-80$ & - & - & - & - & - & - & 3 & $14 \%$ \\
\hline 3 & $66-75$ & 3 & $12 \%$ & - & - & 4 & $15 \%$ & 10 & $45 \%$ \\
\hline 4 & $46-65$ & 6 & $23 \%$ & 14 & $64 \%$ & 16 & $62 \%$ & 4 & $18 \%$ \\
\hline \multirow[t]{2}{*}{5} & $0-45$ & 17 & $65 \%$ & 8 & $36 \%$ & 3 & $12 \%$ & - & - \\
\hline & nlah & 26 & $100 \%$ & 22 & $100 \%$ & 26 & $100 \%$ & 22 & $100 \%$ \\
\hline \multicolumn{2}{|c|}{ Tuntas $(\geq 65)$} & 3 & $12 \%$ & - & - & 7 & $27 \%$ & 22 & $100 \%$ \\
\hline \multicolumn{2}{|c|}{ TidakTuntas $(<65)$} & 23 & $88 \%$ & 22 & $100 \%$ & 19 & $73 \%$ & - & $0 \%$ \\
\hline \multicolumn{2}{|c|}{ Tertinggi } & \multicolumn{2}{|c|}{67} & \multicolumn{2}{|c|}{64} & \multicolumn{2}{|c|}{82} & \multicolumn{2}{|c|}{93} \\
\hline \multicolumn{2}{|c|}{ Terendah } & \multicolumn{2}{|c|}{25} & \multicolumn{2}{|c|}{27} & \multicolumn{2}{|c|}{31} & \multicolumn{2}{|c|}{65} \\
\hline \multicolumn{2}{|c|}{ Rata-rata } & \multicolumn{2}{|c|}{45,69} & \multicolumn{2}{|c|}{46,95} & \multicolumn{2}{|c|}{57} & \multicolumn{2}{|c|}{73,45} \\
\hline
\end{tabular}




\section{Uji Prasyarat}

\section{Uji Normalitas}

\section{Uji Normalitas Pretest}

Uji normalitas digunakan untuk mengetahui apakah data yang didapatkan berdistribusi normal atau tidak. Data yang digunakan adalah data pretest kelas kontrol dan kelas eksperimen. Analisis data menggunakan rumus Liliefors.

Hipotesis yang digunakan adalah Ho: data berdistribusi normal dan Ha: data berdistribusi tidak normal. Kriteria penerimaan Ho, apabila $\mathrm{L}_{\text {hitung }} \leq \mathrm{L}_{\text {tabel }}$.

Hasil pengujian normalitas data pretest kelas kontrol menunjukkan bahwa Liliefors hitung $(0,154)$ kurang dari Liliefors tabel $(0,174)$, maka Ho diterima yang berarti data berdistribusi normal. Dan Liliefors hitung skor pretest kelas eksperimen $(0,091)$ kurang dari Liliefors tabel $(0,189)$, maka Ho diterima yang berarti data berdistribusi normal.

\section{Uji Normalitas Posttest}

Data yang digunakan adalah data posttest kelompok kontrol dan kelompok eksperimen. Analisis data menggunakan rumus Liliefors. Hipotesis yang digunakan adalah Ho: data berdistribusi normal dan Ha: data berdistribusi tidak normal. Kriteria penerimaan Ho, apabilaL $\mathrm{L}_{\text {hitung }} \leq \mathrm{L}_{\text {tabel }}$.

Hasil pengujian normalitas data pretest kelas kontrol menunjukkan bahwa Liliefors hitung skor posttest kelas kontrol $(0,137)$ kurang dari Lilieforstabel $(0,174)$, maka Ho diterima yang berarti data berdistribusi normal. Dan Liliefors hitung skor posttest kelas eksperimen $(0,164)$ kurang dari Lilieforstabel $(0,189)$, maka Ho diterima yang berarti data berdistribusi normal.

\section{Uji Homogenitas}

\section{Uji Homogenitas Pretest}

Uji homogenitas bertujuan untuk mengetahui sebaran data pretest mempunyai varians yang sama atau tidak. Data dikatakan homogen apabila $\mathrm{F}_{\text {hitung }}<\mathrm{F}_{\text {tabel. }}$. Hipotesis yang digunakan adalah Ho: $\sigma_{1}{ }^{2}=\sigma_{2}{ }^{2}$ berarti data memiliki varians yang sama, Ha: $\sigma_{1}{ }^{2} \neq \sigma_{2}{ }^{2}$ berarti data tidak memiliki varians yang sama.

$\mathrm{F}_{\text {hitung }}$ hasil pretest kelas kontrol dan kelas eksperimen $(1,988)$ kurang dari $\mathrm{F}_{\text {tabel }}(2,03)$, maka Ho diterima yang berarti data homogen.

\section{Uji Homogenitas Posttest}

$\mathrm{F}_{\text {hitung }}$ hasil posttest kelas kontrol dan kelas eksperimen sebesar $(1,762)$ kurang dari $\mathrm{F}_{\text {tabel }}(3,105)$, maka Ha diterima yang berarti data tidak homogen.

\section{Uji Hipotesis}

Pengujian hipotesis akhir pada penelitian ini menggunakan uji satu pihak (uji pihak kanan) dengan menggunakan rumus Sparated Varians. Pengujian ini digunakan untuk mengetahui keefektifan pendekatan Contextual Teaching and Learning terhadap hasil belajar IPA materi sumber daya alam.

Rumusan Hipotesis: 
Ho : $\mu_{1} \leq \mu_{2}$ : hasil belajar siswa kelas IV SDN Wonosari 01 pada pembelajaran IPA materi sumber daya alam menggunakan pendekatan CTL kurang dari sama dengan menggunakan pendekatan konvensional.

Ha : $\mu_{1}>\mu_{2}$ : hasil belajar siswa kelas IV SDN Wonosari 01 pada pembelajaran IPA materi sumber daya alam menggunakan pendekatan CTL lebih dari menggunakan pendekatan konvensional.

Tabel 2.

Pengujian Hipotesis Akhir Kelas Kontrol dan Kelas Eksperimen

\begin{tabular}{ccc}
\hline Kriteria & Kelas Eksperimen & Kelas Kontrol \\
\hline Mean & 73,45 & 57 \\
Varian & 65,50 & 240,28 \\
$\mathrm{n}$ & 22 & 26 \\
& $\frac{\overline{x 1}-\overline{x 2}}{\sqrt{\frac{s_{1}^{2}}{n_{1}}+\frac{s_{2}^{2}}{n_{2}}}}$ & \\
$\mathrm{t}_{\text {hitung }}$ & & 4,707 \\
& $\mathrm{n}_{1}-1$ & \\
$\mathrm{dk}_{1}$ & $\mathrm{n}_{2}-1$ & 21 \\
$\mathrm{dk}_{2}$ & $\left(\frac{t_{\text {tabel1 }}-t_{\text {tabel }}}{2}\right)+t_{\text {tabeiterkecil }}$ & 1,728 \\
$\mathrm{t}_{\text {tabel }}=$ & & \\
\hline
\end{tabular}

Pada uji-t dengan menggunakan rumus Sparated Varians, Ha diterima apabila nilai $t_{\text {hitung }} \geq t_{\text {tabel. }}$. Berdasarkan tabel 4.5. dapat diketahui bahwa $t_{\text {hitung }}(4,707)$ lebih dari $t_{\text {tabel }}(1,728)$, maka Ha diterima yang berarti hasil belajar siswa kelas IV SDN Wonosari 01 pada pembelajaran IPA materi sumber daya alam menggunakan pendekatan CTL lebih dari menggunakan pendekatan konvensional.

Nilai N-Gain pada kelas kontrol sebesar 0,26 (rendah) dan kelas eksperimen sebesar 0,50 (sedang). Hal tersebut menunjukkan bahwa peningkatan hasil belajar siswa di kelas eksperimen lebih tinggi dibandingkan kelas kontrol.

Berdasarkan teori belajar Piaget yang mengklasifikan tahap perkembangan kognitif manusia menjadi 4, yaitu: (1) sensori motor (0-2 tahun); (2) pra-operasional (2-7 tahun); (3) operasional konkret (7-11 tahun); dan (4) operasional formal (Shadiq, 2011:27). Siswa SD berada pada tahap operasional konkret (7-11 tahun). Pada tahap tersebut, seorang anak dapat membuat kesimpulan dari situasi nyata atau dengan menggunakan benda konkret. Selain itu, Piaget beranggapan bahwa sejak lahir anak telah mempunyai sistem yang secara terus menerus mencari dan memberi tanggapan terhadap suatu rangsangan dan dengan melakukan hal tersebut secara terus menerus akan membentuk suatu kebiasaan dan kemampuan (Sapriati, 2009:1.7). Dengan demikian, pembelajaran IPA di SD menekankan pada siswa untuk menemukan sendiri pengetahuannya tentang alam sekitar untuk lebih mendalaminya secara ilmiah. Maka pembelajaran dengan menggunakan pendekatan CTL sesuai untuk diterapkan pada 
pembelajaran IPA di SD, karena mengajarkan siswa untuk mengkonstruksi pengetahuannya sendiri dengan mengaitkan pembelajaran dengan kehidupan sehari-hari.

Hasil penelitian tersebut relevan dengan penelitian yang dilakukan sebelummya. Pada penelitian yang dilakukan oleh Ismiatul Jannah dengan judul "Pengaruh Pendekatan Contextual Teaching and Learning terhadap Hasil Belajar IPA Siswa Kelas IV Semester II Madrasah Ibtidaiyah Negeri (MIN) Singaraja Tahun Pelajaran 2013/2014. Hasil penelitian menunjukkan $t_{\text {hitung }}(2,9133)>t_{\text {tabel }}(2,001)$. Hasil tersebut menunjukkan bahwa terdapat perbedaan hasil belajar IPA siswa kelas IV semester II MIN Singaraja yang signifikan antara kelompok siswa yang mengikuti pembelajaran menggunakan Pendekatan Contextual Teaching and Learning (CTL) dengan kelompok siswa yang mengikuti pendekatan pembelajaran konvensional.

Selain itu, penelitian yang dilakukan oleh Samriani dengan judul "Penerapan Pendekatan Contextual Tea-ching and Learning dalam Meningkatkan Hasil belajar Siswa pada Mata Pelajaran IPA di Kelas IV SDN No 3 Siwalempu". Pada penelitian tersebut menunjukkan bahwa penerapan pendekatan CTL dapat meningkatkan hasil belajar siswa kelas IV SDN No 3 Siwalempu, karena model pembelajaran CTL dapat memberikan kemudahan sebagai problem solving, agen of change and social of control dalam pembelajaran.

Peneltian lain yang relevan juga dilakukan oleh Shawn M. Glynn dan Linda K. Winter. Dalam jurnal penelitian (2004:51) yang berjudul "Contextual Teaching and Learning of Science in Elementary Schools" tersebut disebutkan bahwa:

Contextual Teaching and Learning (CTL) integra-tes inquiry, problem and project-based learning, cooperative learning, and authentic asessment. Case studies were carried out on 21 teachers who used CTL to teach science elementary schools to diverse groups of chil-dren. The finding indica-ted that the conditions that fostered the imple-mentation of CTL strate-gies were a collaborative interaction with student, a high level of activity in the lesson, a connection to realworld contexts, and an integration of science content with other content and skill areas. Furtherment, the CTL strategies were best implemented when teachers used them in conjunction with sound classroom management techniques.

Penelitian ini juga didukung dengan penelitian yang dilakukan oleh Hudson dan Wishler dengan judul "Contextual Teaching and Learning for Practicioners" menyatakan bahwa CTL memiliki kelebihan sebagai berikut: "Helping students their own knowledge can be accomplished by guiding them trough scenarios where they are required to actively explore the content in order to reach a goal, solve a problem, complete a project, or answer a question". Hal tersebut mengandung makna bahwa CTL mampu membantu siswa membangun pengetahuan mereka sendiri dengan cara membimbing mereka melalui skenario dimana mereka diwajibkan untuk secara aktif mengeksplorasi konten untuk mencapai tujuan, memecahkan masalah, menyelesaikan sebuah proyek, atau menjawab pertanyaan.

Penelitian yang dilakukan oleh Anisya Septiana dengan judul "Contextual Teaching and Learning Approach (CTL) in Mathematics to Develop Adversity Quotient (AQ)". Dalam jurnal internasional ini disebutkan bahwa: "CTL approach recommended to be implemented in the learning of matematics, because 
theoretically believed to be able of $A Q "$ " Hal ini berarti pendekatan CTL efektif untuk diterapkan dalam pembelajaran matematika.

Dari hasil penelitian yang menunjukkan bahwa $t_{\text {hitung }}(4,707)$ lebih dari $t_{\text {tabel }}(1,728)$, maka Ha diterima yang berarti hasil belajar siswa kelas IV SDN Wonosari 01 pada pembelajaran IPA materi sumber daya alam menggunakan pendekatan CTL lebih dari menggunakan pendekatan konvensional. Serta N-Gain pada kelas kontrol sebesar 0,26 (rendah) dan kelas eksperimen sebesar 0,50 (sedang). Hal tersebut menunjukkan bahwa peningkatan hasil belajar siswa di kelas eksperimen lebih tinggi dibandingkan kelas kontrol. Hasil penelitian ini juga relevan dengan beberapa penelitian yang telah dilakukan sebelumnya, maka pen-dekatan CTL efektif digunakan dalam pembelajaran IPA materi sumber daya alam pada siswa kelas IV SDN Wonosari 01.

\section{KESIMPULAN}

Pendekatan CTL (Contextual Teaching and Learning) efektif digunakan pada pembelajaran IPA materi sumber daya alam pada siswa kelas IV SDN Wonosari 01. Keefektifan pendekatan CTL didasarkan pada pengujian hipotesis dengan menggunakan uji pihak kanan dengan menggunakan rumus Sparated Varians dan diperoleh $t_{\text {hitung }}(4,707)$ lebih dari $t_{\text {tabel }}(1,728)$, sehingga dapat disimpulkan bahwa hasil belajar siswa dengan menggunakan pendekatan CTL lebih efektif dibanding dengan menggunakan pendekatan konvensional. Rata-rata hasil belajar IPA pada siswa kelas eksperimen lebih tinggi dibanding dengan kelas kontrol. Peningkatan hasil belajar IPA materi sumber daya alam pada kelas eksperimen terlihat pada pengitungan N-Gain. N-Gain pada kelas kontrol sebesar 0,26 berada pada kategori. Sedangkan pada kelas eksperimen N-Gain sebesar 0,50 berada pada kategori sedang. Peningkatan pada kelas eksperimen lebih tinggi dibanding pada kelas kontrol.

\section{DAFTAR PUSTAKA}

Glynn, S. M. dan Linda K. W. 2004. Contextual Teaching and Learning of Science in Elementary Schools. Journal of Elementary Science Education, 16, 51-63.

Hudson, C. C. dan V. R. Wishler. 2011. Contextual Teaching and Learning for Practicioners. Systematic, Cybernetics, and Informatics, 6, 54-58.

Jannah, Ismiatul, dkk. 2014. PengaruhPendekatan Contextual Teaching and Learning terhadapHasilBelajar IPA SiswaKelas IV Semester II Madrasah IbtidaiyahNegeri (MIN) SingarajaTahunPelajaran 2013/2014. E-JurnalMimbar PGSD UniversitasPendidikanGanesha, 2:1.

Putra, S. R. 2013. DesainBelajarMengajarKreatifBerbasisSains. Jogjakarta: Divapress.

Rusman. 2014. Model-model Pembelajaran: MengembangkanProfesionalisme Guru. Jakarta: PT Raja GrafindoPersada.

Samriani. 2014. PenerapanPendekatanContextual Teaching and Learning (CTL) dalamMeningkatkanHasilBelajarSiswapada Mata Pelajar IPA di Kelas IV SDN No 3 Siwalempu, $4: 2$.

Sapriati, A. dkk. 2009. Pembelajaran IPA di SD. Jakarta: Universitas Terbuka.

Septiana, Anisya. 2015. Contextual Teaching and Learning Approach (CTL) in Matematics to Develop Adversity Qoutient $(A Q)$. Proceeding of International Conference On Research Implementation and Education of Mathematics and Sciences, 1-6.

Sugiyono. 2015. MetodePenelitianPendidikan. Bandung: Alfabeta. 